\title{
Waarderingswoord
}

\section{Die IRS - 'n kragsentrale van Bybelgetroue denke Dankwoord aan prof. B.J. van der Walt?}

\section{N.T. van der Merwe \\ Potchefstroom}

Graag voldoen ek aan ' $n$ versoek om 'n paar woorde van waardering en dank by hierdie baken in die lewe van prof. B.J. van der Walt gestalte te gee. In besonder raak hierdie waarderingswoord sy werk as direkteur van die Instituut vir Reformatoriese Studie (IRS), die plaaslike Instituut wat spesifiek die lewensbeskouing van die reformatoriese Christendom reeds dekades lank verken en na buite in woord en daad uitgedra het.

In ooreenstemming met die Calvinistiese lewensvisie is hierdie besondere geleentheid in die eerste plek 'n dank, prys en loof van God wat iemand voorsien en toegerus het om hierdie heerlike maar veeleisende taak aan te pak en soveel seen van die Here daarop kon belewe het. Hierdie seën het geblyk uit die groei, uitsette en impak van hierdie Instituut, vér bo wat ooit gehoop of verwag kon word. Daarom is dit tweedens ' $n$ feestelike geleentheid, ' $n$ fees van die oes van die eerstelinge van intellektuele arbeid dekades gelede en van die ingesamelde oes aan die jaareinde ná talle dekades. Want net soos die Israeliete in die destydse heidense wêreld die Tien Gebooie in praktyk kon en moes bring, so was die PU vir $\mathrm{CHO}$ bevoorreg en uitermate geseën om op sý wyse vir 'n geruime tyd reeds die Woord van die lewende God in praktyk te mag bring vir 'n grotendeels gesekulariseerde wêreld: ons hoef nie met leë hande voor die Allerhoogste te verskyn het nie (Eks. 23: 15).

1 Dank- en waarderingswoord aan prof. dr. B.J. van der Walt op 14 November 1999 vir sy taak as direkteur van die Instituut vir Reformatoriese Studie by geleentheid van sy emeritering aan die PU vir CHO. 
Nie met leë hande nie! Vir die aandeel wat ons kollega en vriend Bennie daaraan gehad het, wil ons hom vanaand dank en eer, en in sý persoon ook die PU VIR CHO wat hierdie Instituut tot stand gebring en vir baie jare gedra en ondersteun het, asook spesiaal die toegewyde personeel van die IRS. Wie sou immers, soos Sagaria dit bewoord het (4:10), die dag van kleine dinge verag, terwyl die sewe oë van die Here die ganse aarde deurloop, terwyl dit God is wat die gebou grondves en daarvoor sy diensknegte uitkies? Die klein begin van die IRS as Instituut vir die bevordering van Calvinisme (IBC) in 1962 was gemotiveer deur die toegewyde harte van Christene vir wie die Bybel 'n kragbron en 'n lamp voor die voet was, die Goddelike Woord wat spreek tot hart, verstand en hand. Gedra deur die Afrikaanse Calvinistiese Beweging (ACB) en gesteun deur die PUK onder leiding van sy destydse rektor, prof. H.J.J. Bingle, kon sy entoesiastiese, toegewyde eerste deeltydse direkteur, prof. S.C.W. Duvenage, spoedig versterking ervaar met die benoeming van dr. B. J. van der Walt as eerste voltydse direkteur van die IBC

Spoedig begin die 'stem' van Potchefstroom sterker hoorbaar word na binne en buite. Hierdie Instituut het vér en wyd bekend geword vir sy diverse publikasiereekse, soos die oriënterende en rigtinggewende Studiestukke, die verhelderende Brosjures, die populêre maar diepborende en wetenskaplik deurdagte Versamelwerke, en die spesiale fynproewer-uitgawes van Orientation. Met honderdmyllaarse spring ek na slegs vier voorbeelde ter illustrasie van die breë vlerkslag van onderwerpe en skrywers van Studiestukke - so tydloos (!) dat hulle sonder datum gepubliseer kon word: Nr. 100, J.C. Coetzee: Charismata - geestesgawes; Nr. 200, C.J. Malan: Materialisme: ons dodeiikste vyand; Nr. 300, M. Scott: A Christian perspective on motivation; en ten slotte een van die mees resente, nr. 381, B.J. van der Walt, P.G.W. du Plessis en G.J. de Klerk: Christelike waardes in die nuwe Suid-Afrika. Van die byna 400 aktuele Studiestukke is verskeie van die hand van professor Van der Walt. Tot die sowat 70-sterk Brosjurereeks het hy 16 bygedra, waarby sy studies oor die Calvinistiese verlede, oor die mens, en oor kultuur - veral in Afrika - opval. Sowat 'n vyftig versamelwerke het onder sy inspirerende leiding - en volgehoue perspirasie - die lig gesien. Dit is aan sy vaardigheid met leiding gee aan denkskrums te danke dat hierdie projek solied begrond kon word, maar tegelykertyd 'n wye leserskring kon interesseer en nie slegs 'n klein intellektuele elitegroepie nie. Tot talle het hy self behartigenswaardige bydraes gemaak wat nuwe perspektiewe oopgeboor het, of - in 'n meer toepaslike en bekende metafoor uitgedruk - 'n venster op die onderwerp oopgemaak het. Met die Vensterreeks is inderdaad uitsigte vanuit 'n omraamde uitgangspunt gebied oor temas waaroor weinig literatuur bestaan het. Sy vier monografieë in dié reeks het daaraan aansien verleen. Sy persoonlike betrokkenheid saam met mevrou Rita Swanepoel by die kontakblad 
N.T. van der Merwe

van Christelike inrigtings vir hoër onderwys uit die Reformatoriese tradisie, Orientation, het hierdie publikasie uniek in die wêreld van Christelike onderwys gemaak. Deur sy veelvuldige kontakte wêreldwyd was hy tewens in staat om ywerig en kundig die doelstellings van die "International Association for the Promotion of Christian Higher Education" bekend te stel en sodoende die belang van Christelike onderwys oor landsgrense heen te bevorder.

Tot slegs die geskrewe woord het die 'stem' van Potchefstroom nie beperk gebly nie. Die verdienstelike van die saak was dat dit uitgekring het en geresoneer het in die diverse aanvullende en soms ook krities onderling slypende klanke van 'n koor van woord en daad: deelnames op radio en televisie benewens by talle konferensies (plaaslik, nasionaal en interndsionaal), asook verkenningstogte, aanbiedinge en kursusse tot diep in die hart van Afrika, soms met groot persoonlike opofferinge en ontberinge.

'n Instituut soos die IRS het 'n saaklike en 'n persoonlike kant. Tot die saaklike behoort ook die groei van die IBC tot die huidige IRS met belangstellende ondersteuners en lede wêreldwyd. Kort gestel, kan 'n mens sê dat dit in internasionale samewerking met ander Christelike instellings steeds ruimer die erfenis van die verlede, teruggaande tot die 16de-eeuse Reformasie - waaronder die diep insig van 'n semper reformanda-motief vir die toepassing van 'n reformatoriese lewensvisie verken, verdiep en in praktyk gebring het. Met die visier gerig op aktualiteit en relevansie is gemeenskaplike Bybelse waardes moedig beskerm en verdedig. Brosjure nr. 21, die feesbundel by geleentheid van die twintigjarige bestaan van die Instituut in 1982, bied hiervan al 'n waardevolle aanduiding. Prof. S.C.W. Duvenage wys byvoorbeeld op die belang van radikale (nie-revolusionêre) reformasie en multidissiplinêre groepswerk vir die bevordering van die taak van die IRS en prof. T. van der Walt op die noodsaak om die doelgerigte hulpdiens van die IRS as 'n kragsentrale van radikale Bybelse denke en doen in die toekoms aansienlik uit te brei, te verdiep en te verstewig.

In ooreenstemming hiermee het die IRS ná 1982 ook sterker sosiaal betrokke en Afrika-gefokus ontwikkel. Wie sal ooit die blye gesigte van twee Christene vergeet wat uit midde-Afrika wekelank per voet, boot, fiets, trein en bus eindelik by ' $n$ IRS-konferensie opgedaag het, om hier met 'n nuwe visie vervul te word? Van hierdie visie getuig ook die kwarteeu-feesbundel van 1987, Visie en missie - IRS 25 jaar, op 'n besondere wyse. Dit is merkwaardig dat prof. Van der Walt hierin die taak van die IRS in die koninkryk van God nie as 'n venster nie, maar as 'n brug bestempel, 'n strategiese brug wat missionêr met 'n heilige geroepenheid die bevrydende perspektiewe van 'n reformatories-evangeliese lewensvisie die wêreld indra (p. 5). Hierdie visie behels tewens 'n 
groter missie vir die PUK: in 1982 het prof. T. van der Walt reeds op die belang van betrokkenheid by die Ooste gewys. Die Direkteur van die IRS kontekstualiseer dié betrokkenheid in 1987 heel spesifiek deur te benadruk: Afrika roep! Ons eer en dank prof. Van der Walt vir sy publikasies oor die Christendom in Afrika, vir die verskillende reise dwarsoor Afrika waarin hy die geestelike klimaat van talle lande gaan verken en die PU vir $\mathrm{CHO}$ aan 'n verskeidenheid gemeenskappe bekendgestel het deur die betekenis van 'n Reformatories-Christelike lewensvisie vir Afrika eenvoudig, helder en betekenisvol toe te lig. Die beslissende vraag vandag - twaalf jaar later - is hoe hierdie basiese taak lokaal én wêreldwyd volgens die eise van die tyd volvoer kan word.

Tot die persoonlike kant van die instituut behoort onder andere sy Direkteur, en daarom vermelding van sy buitengewone hardwerkendheid en stiptelikheid (meestal ' $n$ jaar vooruit gereed!), sy besielende roepingsbesef en toewyding, sy voorbeeld met die reformeer van wetenskaplike ideë, en sy moedige getuig vir die boodskap wat sy Instituut tot ' $n$ missie verwerk het, selfs al sou dit soms verguising en eensaamheid meebring wanneer sommige die visier hoër en ander daarenteen laer wou stel; sommige van mening was die IRS te vinnig met uitwys en aanpak van kontemporêre vraagstukke beweeg, ander weer gevoel het dat daar gesloer word, en so meer. Opmerklik is sy openheid vir kritiek en konstruktiewe voorstelle as dit maar begrond is, asook vir alternatiewe benaderinge vanuit die prinsipiële wortel. Inspirerend is sy humorsin en die warm dinamiese nadertrekkrag wat uit sy persoonlikheid straal, waarmee hy menige besoeker aan sy Instituut 'n nuwe sig op die Calvinisme en op die Christendom gegee het. Dit sou sy studente dikwels besiel tot interessante kreatiewe gemeenskaplike ondersoekprojekte, wat hulle met 'n visie en taakbesef die lewe ingestuur het. As dienskneg in die koninkryk van God was hy inderdaad 'n sendeling in verskillende gedaante en mantel.

As vriend is hy en sy vrou Hannetjie gulhartig, mededeelsaam en gasvry - dikwels meer begaan daaroor om ook aan ander rus, vrede en geestelike herstel tuis of in die natuur te besorg as wat hul eie behoeftes dikteer. Sy het inderdaad verstaan wat Psalm 90 bedoel met "leer ons ons dae tel sodat ons ' $n$ wyse hart mag bekom". Haar stille krag en wysheid het nie alleen die onafgebroke lang ure wat hy op kantoor moes deurbring, verdra nie, maar hom ook deur al die jare positief begelei, aangemoedig en geslyp. Die sukses van die IRS is mede aan haar te danke. Daarom sluit ek met ' $n$ saluut aan albei. Ek bid hulle vir die toekoms toe die gevleuelde woorde van hierdie Psalm: "Laat die lieflikheid van die Here onse God oor ons wees, en bevestig die werk van ons hande oor ons, ja, die werk van ons hande, bevestig dit"! 